\title{
Neighborhood from Cul-De- Sac to Gated Community in Turkish Urban Culture: The
} "Fina"

Havva Alkan Bala*

Abstract

In this study, the closed neighborhood was discussed in gated communities and in cul-de-sacs by focusing on public and private concepts, rights and regulations in Turkish urban culture. The study aims to enlighten old concepts such as "close neighborhood," "gated community," and "cul-de-sac" with a new approach in order to understand whether planned and modern gated communities contain the same aspects of traditional Turkish cul-de-sacs - part of the "fina" concept. According to tradition and culture, the concept of fina is a kind of usage of public space as if it were private. In the modern age, gated communities have created new life styles, spaces and boundaries with their advantages and disadvantages all over the world. The gated community may be called an "architecture of fear," namely fear of the neighbors, fear of theft, fear of the one living outside the gates. On the other hand, cul-de-sacs are derived from friendships and family relations - namely, being friends with relatives, neighbors and nature. Gated communities and cul-de-sacs are both created by making public space belonging to all citizens - into private/semi-private space belonging to only a special community. A comparative method is used between gated communities and cul-de-sacs in order to understand whether the legalization of using public space in private ways creates benefits to
Keywords: Gated community, fina, culde-sac, neighborhood, anatolian cities

*Prof. Dr. Havva Alkan Bala, Faculty of Architecture and Design, Konya Technical University, Konya, Turkey.

E-mail: halkanbala@gmail.com Orcid ID: https://orcid.org/0000-00020027-7531 
society as a whole or not. The result expected from this study is not only to determine the similarities and differences pertaining to cul-de-sacs and gated communities but also to reveal the positive values generated or existing in these two living areas and provide feedback with the potential of reflecting each other.

\section{INTRODUCTION}

The study compares gated communities and cul-de-sacs with new perceptions focusing on the usage of "public space as if it were private/semi-private." in Turkish urban culture. It defines the "gated community" as a different kind of cul-de-sac, and vice versa - an idea that is very uncommon in the literature on gated communities. To define modern gated communities as spatially the same as closed traditional cul-de-sac settlements may be both original and risky. The risk comes from the many differences between traditional cul-de-sacs and modern gated communities, such as: main reason(s) for privatizing public space, usage of technology, socio-economic inputs, neighborhood / friend / family relations, cultural values and general life styles. However, when we make an in-depth analysis of the two free from prejudice, we may see some common or even the same characteristics.

Cul-de-sacs and gated communities are created by changing public space that belongs to all citizens into private/semi-private space belonging to special groups only. Both cul-de-sacs and gated communities may be called "closed neighborhoods." In order to understand the aim of this study, first, the concepts of the closed neighborhood, the cul-de-sac and the gated community should be defined, but to define these concepts may not be enough, since culture creates changes in the usage and meaning of space. The gated community was developed due to contextual reasons in Canada, the United States and Europe. In Turkey, similar gated communities have been copied and created without questioning their roots. Similarly, the Turkish "çlkmaz sokak" (literally, "street without an exit") is not the same as a cul-de-sac. Terms such as gated community and cul-de-sac are used in English, but not referring to a North American or European spatial culture but referring to a Turkish spatial urban culture.

\section{METHODOLOGY}

The comparative method between gated communities and cul-desacs case studies in Konya consists of analysis by observation and interview. The comparative method between gated community and cul-de-sac is used to find out whether legalization of the privatization of public space creates benefits for the whole picture or not. Case studies in Konya for cul-de-sac and gated community 
are analyzed by observation and interview. Konya, located in central Anatolia, is of great importance as regards culture, economy, history and space. This study focuses on two typical examples of "Pervasız" cul-de-sac and "Beyzade" gated community in Konya as a case study .

\section{Assumption and Scope of The Study}

As previously mentioned, "gated community" is defined as a different kind of cul-de-sac, and vice versa in this study. This claim is based on two assumptions. The first is that access to traditional cul-de-sacs and modern gated communities in Anatolia is the same: one-sided access using public space as if it were private/semi-private (Figure 1).

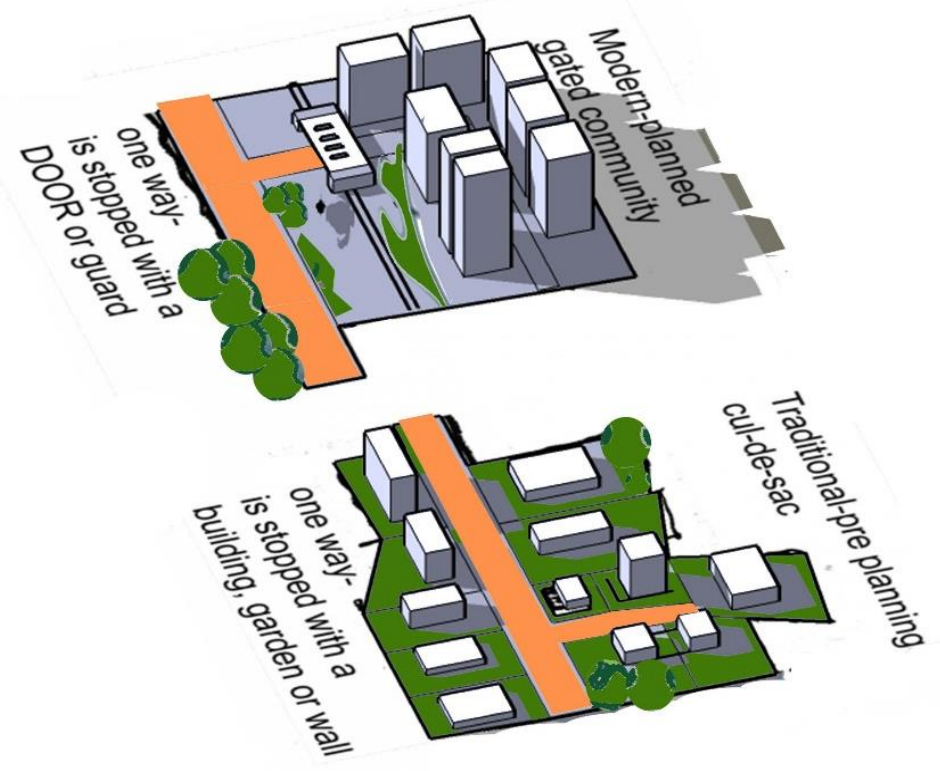

The second assumption of the study is that, in both cul-de-sacs and gated communities, human relationships between relatives, friends and especially neighbors are very relevant in the decisionmaking process of where to live. Despite the fact that modern life has changed the perception of neighborhood relationships in Turkish society in general, human relationships between relatives, friends and neighbors in smaller Anatolian cities can still be found as compared to larger Turkish cities in Europe and North America.

\section{BASIC CONCEPTS: “USING PUBLIC SPACE AS IF IT WERE PRIVATE/SEMI-PRIVATE” IN A CLOSED-NEIGHBORHOOD}

What is a closed-neighborhood and why does it come about? According to Webster (2002), Ladman (2002, 2004) and Fabiyi (2004), the main reasons of a closed neighborhood are to control local crime and increase their social standing. Olusevi (2006) claims that closed neighborhoods, becoming part of the city
Figure 1. One-sided access to traditional cul-de-sacs and modern gated communities in Anatolia (drawn by author,2018). 
circulation pattern, make some citizens' lives easy, but put others in a difficult situation by preventing emergency access.

"Using Public Space As If It Were Private/Semi-Private" in a closed-neighborhood is an issue of urban interface in the city. On the horizontal axis, urban interfaces are voids that remain between buildings and concern building/mass and their composition, and on the vertical axis, they are places of interaction and transition that are composed of the sum total of architectural façades and located at the intersection of architectural products and urban space. Interfaces establish visual and functional connections as outer surfaces of urban spaces on the one hand and walls of built-up environment reflected from the interior to the exterior on the other in the context of naturecity, private-public, interior-exterior, positive (mass/solid)-negative (void) and urbanization-architecture (Bala 2003). The statement "Using Public Space as if It Were Private/Semi-Private" is worth discussing because closed neighborhoods make public rights as community rights.

Streets are a major part of urban space and they are the most integrated part of the residential area that provides a different usage (Rykwert 1982). According to Newman (1972), a public space refers to an area or place that is open and accessible to all citizens, regardless of gender, race, ethnicity, age or socioeconomic level. Before discussing closed neighborhoods further, it may be useful to mention the perception of public-private terminology in Turkish culture. The concepts of and the relationship between "public" and "private" in Europe and North America are different from those in Turkey, both historically and today. According to Islamic law, an owner's property is sacred. People could use common rights, as is their own property without doing damaging to it (Çelik 1996; Çevik and Özen 1995; Yerasimos 1996). During the Ottoman period in Turkey, there was an indistinct and permeable relationship between public and private. That is, the hierarchy between public and private was supported by semi-public and semi-private spaces in Turkish urban culture. The boundaries between public and private territory in the modern city have been defined by cartographic techniques. In modern cities today, boundaries of public space are very strict, well-defined, but very "thin." However, in pre-modern Turkey, boundaries between public and private spaces were "thick. "In such transitional zones, "private" diffuses into the territorial area of "public" (Figure 2). 


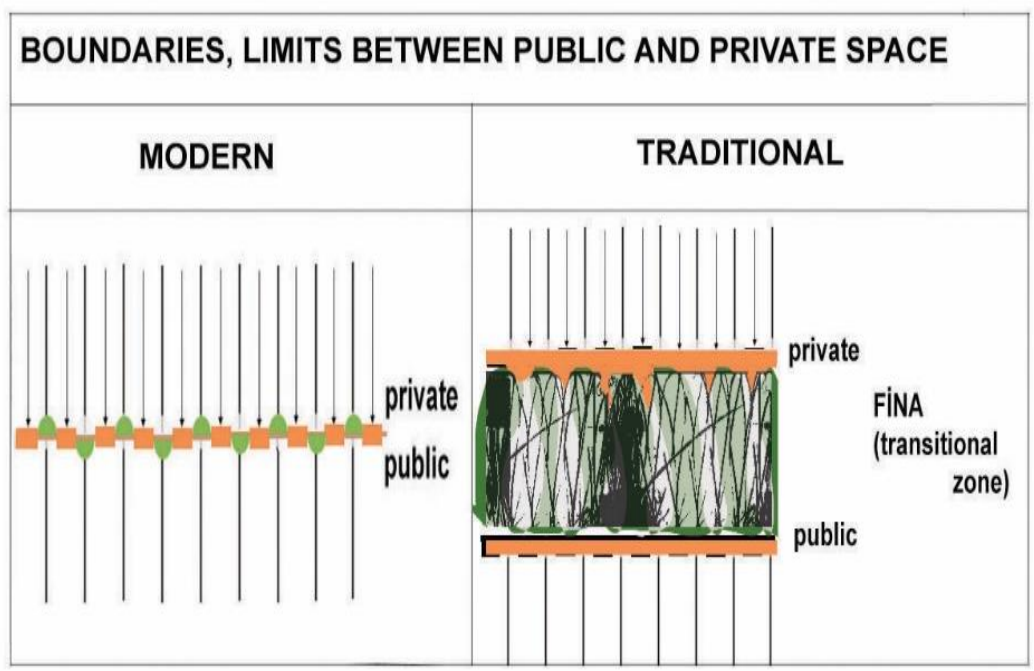

This is a territorial space perception that turns public space into a private/semi-private space. In contrast to Western perception, such a situation is seen as positive. In Ottoman city culture, private rights had a strong power on public boundaries. These transitional zones between public space and private space were valuable for daily city life in the traditional Ottoman city street (Yerasimos 1996). During the Ottoman period in Turkey, there was a tendency to promote private space as overlapping, violating public space in the city. Güner (2010), referring to Uğur Tanyeli, says that public space which "belongs to everyone" in Western culture is equivalent to public space which "belongs to anyone" in the Ottoman period. Thus, "Using Public Space as if It Were Private/Semi-Private" creates an extra positive value, so it was legal during that period. The boundaries between private and public space were composed of transitional zones of semi-private and semi-public areas. In Islamic cities, this concept of a boundary separating private and public property from each other is called "fina". The term fina is used in place of border, which means progressive transfer from one unit to another. Fina is an Arabic term that is also synonymous with the term "Harim," which refers to an invisible space about 1 to 1.5 meter wide alongside all exterior walls of a building that is not attached to other walls, and primarily alongside streets and access paths. It extends vertically alongside the walls of a building. The owner or tenant of a building has certain rights and responsibilities associated with its fina. The owner has the right to use it for temporary purposes, provided that such use will not disturb the environment and others, and the tenant has the responsibility to keep his part of the fina always clean and safe from any obstructions. Habitable space in a fina exists vertically in the form of balconies, enclosed bay windows, and rooms bridging the public-right-of-way (called Sabat) (Hakim 2007, 2010) (Figure 3).
Figure 2.The concept of boundaries between public and private space in the traditional and modern citv(drawn by author,2018). 
Figure 3.Left: Photograph of street with a "fina." Right: Sketch of street with dark areas and solid lines indicating elements allowed within the "fina" (Bala,2010).
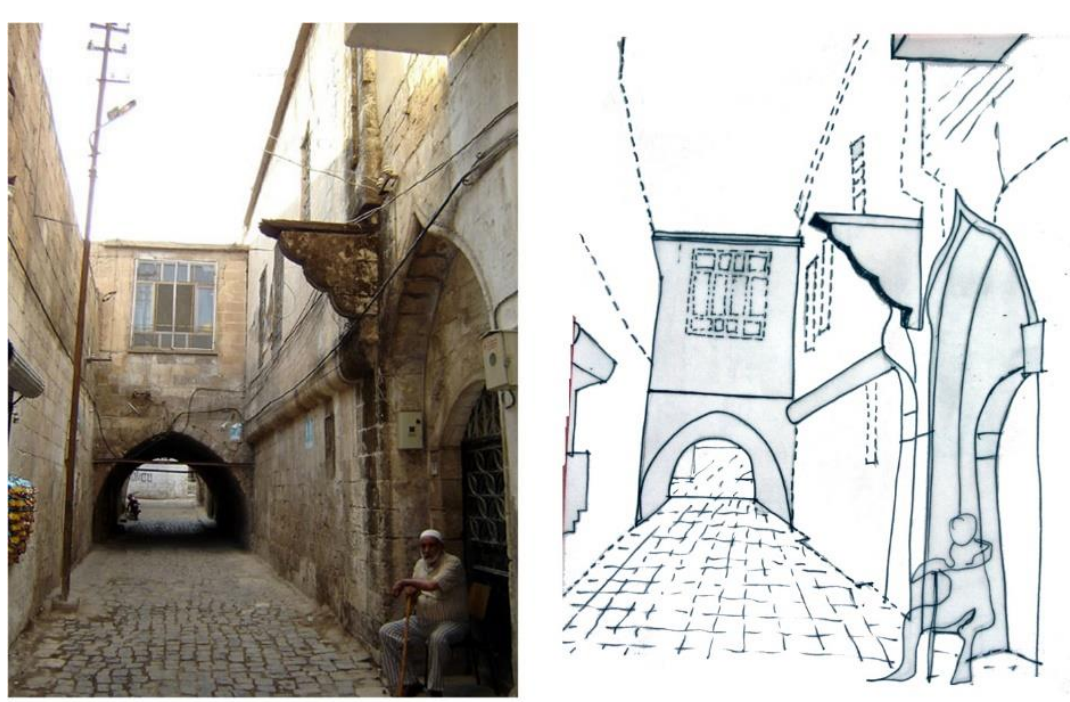

Güner (2010), referring to Tanyeli (2005), all kinds of public spaces in the Ottoman city - including streets and mosque squares - were a kind of reserve spaces to make them private. For centuries there was no attempt formally and informally to prevent "Using Public Space as if It Were Private/Semi-Private," because the person who extended his plot to the street never thought that he had stolen public property or violated any public right. When we are talking about a culture that does not need to define the public space, no one would be worried about infringing upon the rights of the public. In this culture, privatization of public space belongs to anyone who creates extra values without disturbing other people, nature and the built-up environment.

\section{Comparison of Cul-De-Sacs and Gated Communities with Respect to Property Rights}

A "çlkmaz sokak" in Turkish (literally, "street without an exit") is neither a cul-de-sac nor a dead-end street (Balamir 1994). Components of cities are arranged in such a way that they reflect their relevant cultures (Hillier and Hanson 1984). Cul-de-sacs in traditional Turkish cities also represent Turkish as well as Islamic city culture. Medieval Cities in Europe had dead-end streets, similar to the ones in Turkey. However, the usage and the approach to cul-de-sacs were completely different in each case (Bala and Nafa 2008, Bala and Yodaş 2008, Bala et al. 2009, Bala 2010).

The cul-de-sac is defined in architecture and urban design literature as "the street pattern open only in one side and connected to other larger streets" (Sözen \& Tanyeli 1992; Keleş 1999; Southworth \& Ben-Joseph 2004; and Cozens \& Hillier 2008). Cul-de-sac as a word has a negative semantic connotation in Europe and North America. In English, "dead-end street," "blind alley," and "blind path" are all used, as well as cul-de-sac, to imply 
dead, numb, lazy, sluggish, lethargic, shiftless, or indolent behavior "going nowhere." This approach may come from the general idea that cul-de-sacs have come to symbolize problems of suburbia - an isolated, insular enclave, set in a formless sprawl of similar enclaves, separated socially and physically from the larger world, and dependent upon the automobile for its survival. Culde-sacs seen in medieval cities (Morris 1979; Mumford 1989; Moughtin 1992) do not have the same peculiarities with the deadend streets of Ottoman and Islamic cities. Traditional Turkish cities were organic and free, not geometric and in rhythmic order (Aru 1998; Kubat et al., 2001, Kubat ve Topçu 2009). Traditional Turkish cities are typically composed of a network with a large number of cul-de-sacs and winding and narrow roads in human scale just like a tree system (Grünebaum 1946; Lapidus 1967; Hassan 1972; Acar 1975; Saoud 2002; Abu-Lughod 1987 \& Hakim 2007; Bala ve Nafa 2008; Bala and Yoldaş 2008). According to Berktay (1996), in this hierarchical tree system, the main road was just large enoug to allow for the passing of horses. Islamic cities are not designed so that someone can pass from one point to another, one quarter to another as one wishes. There is a soft, gradual and hierarchical transition from the most public spaces like a mosque, bazaar, square, large street or garden gate - to the most private spaces like a garden and house. According to Yerasimos (1996), the status of the dead-end street is a wonderful example in terms of the priority of the rights of a natural person. Every resident is a partner to the property, which starts from the entrance of a dead-end street and ends at the threshold of his house (Yerasimos 1996, Bala and Nafa 2008, ,Bala and Yodaş 2008, Bala et al. 2009, Bala 2010). Grünebaum (1946) has wondered why Muslim cities have given up using "the advantage of a straight line as the best route from one point to another" and instead preferred narrow streets that end abruptly. However, as will be discussed, it is not so much a case of "giving up" but a case of such a convenience never being a priority in the creation of street layouts (Grunebaum 1961; Hannah 1985; Stein 1974), (Hassan 1972; Saoud (2002); Lapidus (1973); Acar (1975), Petherbridge (1984); Hakim (2007); Abu-Lughod (1987), Ettinghousen (1973); Erdem and Özcan 2004; Sauvaget 1946). Andre Raymond $(1994,1995)$ mentioned that a comparison of Western medieval cities and their urban institutions and an Islamic city shows that the latter has lost the regularity of an antique city. Roger (1996) uses typical words such as; "Nothing is more foreign to a Muslim town than the rectilinear avenues of a Roman or a modern city; an aerial photograph of any Muslim city makes us think of a maze, or a labyrinth. Instead of being integrated into a planned design, the buildings have forced the communication routes to skirt round them, or to slip between 
them as best they could. As a result, there are an extraordinary number of dead-ends and the roads are very rarely straight". Gustave von Grunebaum (1946) wonder why Muslim cities have given up using "the advantage of a straight line as the best route from one point to another" and preferred narrow streets ending abruptly. J. Sauvaget (1946) claims that "the Islamic city is no longer considered as an entity, as a being in itself, complex and alive; it is just a gathering of individuals with conflicting interests who, each in his own sphere, acts on his own account. There are no more municipal institutions". Cul-de-sac is either a semiprivate or semi public road for residential groups located along the road without reaching outside and providing people or others one-way access. Nevertheless, much can be said in favor of the culde-sac street as a pattern for neighborhood space in Europe and USA (Southworth and Ben-Joseph 2004). This idea based on a quiet, pedestrian-focused environment was created where courts and close arrangements of terraced houses bordered a central green space accessed by a narrow service road connected to the public street system.

The phenomenon of dead-end streets turns public areas into private areas in accordance with the "fina", enabling transfer from one property to another in Islamic law (Yerasimos 1996). It is a kind of "Using Public Space as if it were Private/Semi-Private" process based on the agreement of property owners of buildings having a surface facing towards a dead end. Like dead-end streets, cul-de-sacs and gated communities also give clues about how families, neighborhoods and other social relationships change according to urban layout, as well as being good examples of how to turn public spaces to semi-private.

\section{The Roots of Cul-de-sac}

Cul-de-sacs in the Islamic/Ottoman context mainly deal with segregation, privacy through space hierarchy and control (Aktüre 1978; Stewing 1966; Lapidus 1967 and Bala \& Nafa 2008, Bala et al. 2009, Bala and Yoldaş 2009, Bala 2012)). The Cul-de-sac has been a space of social interaction bringing relationships between relatives and neighbors closer (Figure 4). 


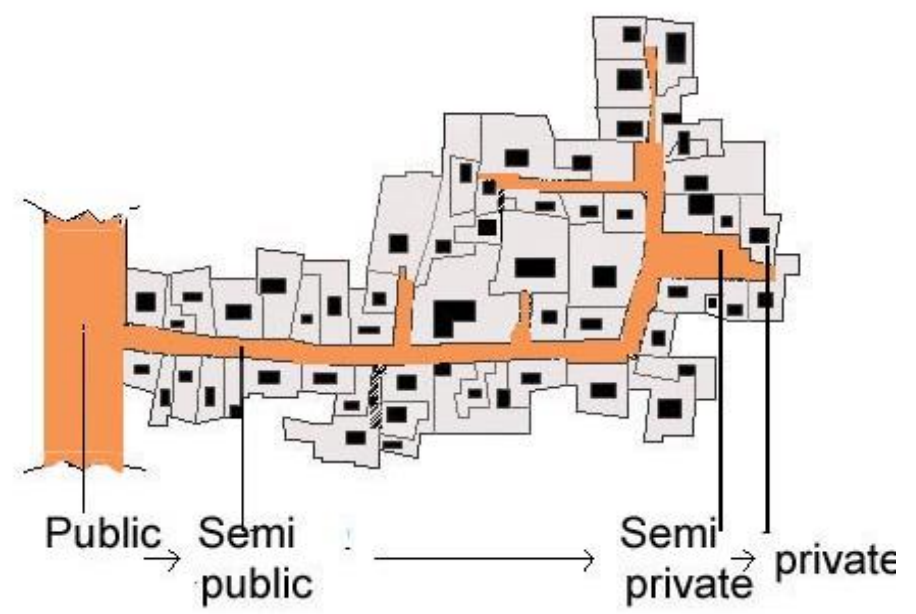

There is a common social reality in traditional Turkish culture that if sons have carried the honor of all the family, then the family roots and relationships are strong and when a son gets married, he cannot leave the larger family alone, so an extension is added to the family house. These houses constitute a dead end by attaching to two separate houses across a street. Two houses facing each other are joined together and constitute two new ends (Figure 5).
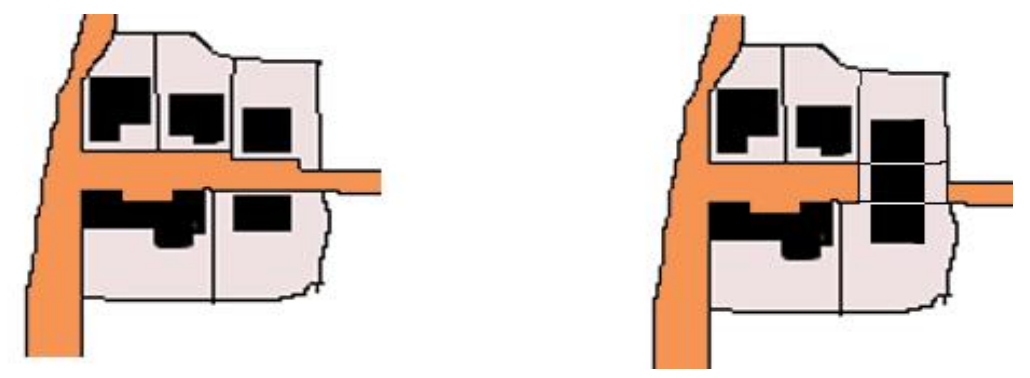

Such a situation is not technically legal considering building regulations within a universal perspective, but it is in fact in line with Ottoman traditions (Yerasimos 1996). In traditional Turkish culture, each member of society must be careful about the others' rights considering the spiritual world. None of the neighbors would construct his house in a selfish way. They were careful about nature, context and neighbors. In other words, people constructed their houses in a way that their buildings did not block incoming sunshine and did not close the view of their neighbors. They have also never destroyed trees or any creature's habitat. All this behavior is in keeping with "mortal rights" according to Islam. To ignore the "mortal right" of an individual is one of the biggest sins according to Islam. Thus, traditional Turkish cities respect nature, context and neighbors' rights. Considering urbanism, religious rules were much stronger than the official rules at that time. According to Stewing (1966), Islamic rules attach more importance to private property rights than
Figure 5.An extension added to a house makes a dead-end street by bridging houses across from each other (Bala 2012, Bala 2010, Bala ve Nafa 2008)l

Figure 4.The cul-de-sac can be either a semi-private or semi-public road for residential areas (Bala 2010, Bala 2012) 
public property rights as long as they do not do directly harm other people. Islamic city culture defined the spatial and physical structure of dead ends.

In Islamic cities, private property is more important than public property and the concept of border is shaped through this understanding. There are common property areas in Islamic cities; however, public benefit liabilities are not applied in these areas as they are applied in Europe and in North America (Stewing 1966). Private property is more important than public property, and an interface is created, which is called 'cul-de-sac.' (Stewing 1966; Yerasimos 1996). The owner of a private property can occupy the street in front of his property; moreover he can have the right to use this area permanently. Therefore, this street becomes his "fina." By permission of street residents, two neighbors facing one another may interrupt a road and divide it into two dead-end streets. These two dead-ends become the property of the residents. Therefore, people in this area would privatize the public area. According to Denel (1982), administrative, legal and economic alterations were observed in countries under the rule of the Ottomans after the proclamation of reforms in 1839 (which were a series of six legislative regulations passed between 1848-1882 adopting Western views). These alterations comprise the transforming of the traditional Ottoman city pattern into grids by deteriorating traditional city patterns with new boundaries, property and rights. In modern cities, streets are designed for motor vehicles rather than pedestrians. Thus, development plans propose a grid system and forbid creating cul-de-sacs. In recent years, the cul-de-sac has become both elongated and widened, with more dwellings incorporated. Some urban analysts and planners turned to the Garden City model, and winding streets, crescents and irregular shapes came to dominate urban thinking and design throughout much of the twentieth century.. New Urbanism promotes highdensity, mixed-use residential developments in 'walkable' neighborhoods close to public transport, employment and amenities and generally advocates the use of the grid street layout in preference to the cul-de-sac (Morrow-Jones et al., 2004), (Duany and Plater-Zyberk 2003-1992), (Calthorpe 1994), (Kartz 1994), (Cozens and Hillier, 2008). Southworth and Ben-Joseph (1997) note that the term cul-de-sac has become pejorative among many architects and planners, because it represents the essence of suburbia today. Southworth and Ben Joseph (1997) also argue that it is possible to design easily (accessible) residential districts that are interconnected to vehicular system. Nevertheless, the modern approach generally defines a cul-de-sac as an isolated, insular, private enclave, set in formless, sprawl or 
similar enclaves, separated socially and physically from the larger world and dependent upon the automobile for its survival (Carmona et al. 2003). Although the cul-de-sac has a function for being a transitional space between public and private space in traditional Turkish cities, they have all but disappeared in modern ones.

\section{The Roots of Gated Communities in Turkey Today}

In the modern age, gated communities have created new life styles, spaces and boundaries with their advantages and disadvantages all over the world. The gated community may be called an "architecture of fear," namely fear of the neighbors, fear of theft, fear of the one living outside the gates. On the other hand, cul-de-sacs are derived from friendship and family relations namely, being friends with relatives, neighbors and nature. A gated community is, in simple terms, a community surrounded by a fence and provided with a gate for entrance. In recent years, numerous papers, articles and books have been published on gated communities and in general gated communities are considered in the light of urban segregationist tendencies (Roitman 2005). In this study, the gated community will be analyzed by comparing them with cul-de-sacs in terms of making a public space serving a community. While gated communities have legal authority to withhold access to outsiders, defended neighborhoods do not have this authority. This legal aspect is important in relation to another aspect. "Open" space within a defended neighborhood should be considered public space, while all space within a gated community should be considered private. However, when public space becomes privatized, accessibility is a major issue because public space is broken down.

The physical boundary defines not only spatial separation but also social separation. There is a large body of research which links segregation with economy, poverty and the lower class (Wilson 1987; Massey \& Denton 1993; and Mingione, 1996). Urban violence and fear of crime are usually mentioned as the main reasons for moving to a gated community (Blakely \& Snyder 1997; Carvalho et al., 1997; Caldeira 2000; Greenstein et al. 2000; Low 2000; Svampa, 2001; Borsdof 2002; Landman 2002; and Pinto \& Rovira 2002). Many authors have referred to the process of choosing a gated community as an act of voluntary segregation, a conscious act and decision taken by an individual or family, contributing to the process of urban social segregation (Greenstein et al., 2000; Borsdorf 2002). Researchers such as Wilson-Doenges (2000) have showed that gated communities are not such a safe place to live. On the other hand, it is important to note that although most of the time the bad effects of living in a 
segregated place, which is not only segregated but poor as well, are highlighted, living in a segregated but wealthy place like a gated community also has many drawbacks for its residents. Social segregation hardens and breaks the social fabric through the use of visible barriers that do not allow strangers to go inside the borders of the gated communities. It reinforces social differences and social divisions. There is a lack of contact with different people. Construction of social relations is influenced by the separation established between 'the insiders' and 'the outsiders'. 'The others', who are the people outside and especially the neighbors in the surrounding areas, are perceived by residents of the gated communities as strangers and as potential aggressors. In this way, physical barriers are used to establish a distance, which is not only physical, but also social and symbolic. A gated community features the same characteristics as a defended neighborhood, but is also gated and walled, frequently with a central guarded entrance. Within a defended neighborhood, road and other signs as well as a (closed) video circuit often suggest that it is a private property, while this is not the case. The cameras and signs are meant to make outsiders understand that they do not belong there. Most gated communities not only make this known at the entrance, but also within the gates. While gated communities have legal authority to withhold access to outsiders, defended neighborhoods do not have this authority. The legal aspect is important in relation to another aspect. 'Open' space (with the exception of private gardens) within a defended neighborhood should be considered 'public space', while all space within a gated community should be considered 'private'. The private entity responsible for maintenance of the 'open' space is the homeowner association. However, public space thus becomes privatized or parochialized and accessibility is a major issue because public space is broken down. This phenomenon involves a group of residents who choose to live in a designated location surrounded by a protective system. They have security devices such as walls, fences, gates, barriers, alarms, guards and CCTV cameras. By and large, the infrastructure and services are of a high quality. They are designed with the intention of providing security to their residents and prevent penetration by non-residents, being conceived as closed places since their inception. Law reinforces their closure as private places, which distinguishes them from other places in the city. Their residents must follow a code of conduct concerning social behavior and construction regulations. Gated communities appear as homogeneous places in comparison to the heterogeneity of the 'open city'. Most of their residents are upper- and middle-class families. Urban violence and fear of crime are mentioned in the literature as the main reasons for moving to 
a gated community (Blakely and Snyder, 1997), (Caldeira, 2000), (Carvalho et al., 1997), (Landman, 2002), (Low, 2000), (Pinto and Rovira, 2002), (Borsdof, 2002), (Svampa, 2001), (Greenstein et al. 2000). Many authors have referred to the process of choosing a gated community as an act of voluntary segregation, a conscious act and decision taken by an individual or family, contributing to the process of urban social segregation (Borsdorf, 2002), (Greenstein et al., 2000). Other authors say that gated communities represent a special type of segregation (Carvalho et al., 1997), (Marcuse, 2001). Gated communities contribute to a type of segregation that cannot be defined as either voluntary or subjective, but rather influenced by both (Roitman 2005).

\section{SAMPLE AREAS OF CUL-DE-SACS AND GATED COMMUNITIES IN KONYA}

The comparative method between gated communities and cul-desacs case studies in Konya consists of analysis by observation and interview. Konya is located in central Anatolian plain of Turkey. Konya was the capital of the Greater Seljuk Empire (1037-1194) and has accumulated a great wealth of cultural, economic, historical and spatial significance over many years of its existence. Konya became urbanized because of its logistical location (Baykara (1985). Being in the heart of Anatolia and being the capital of the Seljuk Empire gave a strong base to Konya regarding urban construction, infrastructure, social development and cultural richness. Thus, there are so many cul-de-sac in the city. Since the beginning of 2000s, gated communities started to rise. According to Topçu (2013), luxurious gated housing that appeal to upper middle classes emerged in the property market in Konya within the last ten years. This study focuses on two typical examples of cul-de-sacs (Pervasız Sokak) and gated communities (Beyzade Housing) in Konya as case studies. The author has lived in Konya and has observed the spatial development of the city over many years. This input is also another reason why this city has been chosen (Figure 6). 

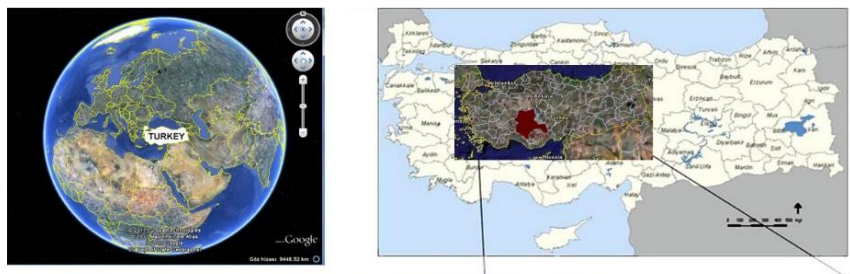

Figure 6.Konya: Alaeddin Hill and Mevlana Tomb (museum) are the landmarks; the areas of study are marked.

Figure 7.The selected cul-de-sac, Pervasız Çlkmazl, and the selected gated community, Beyzade Housing Complex.

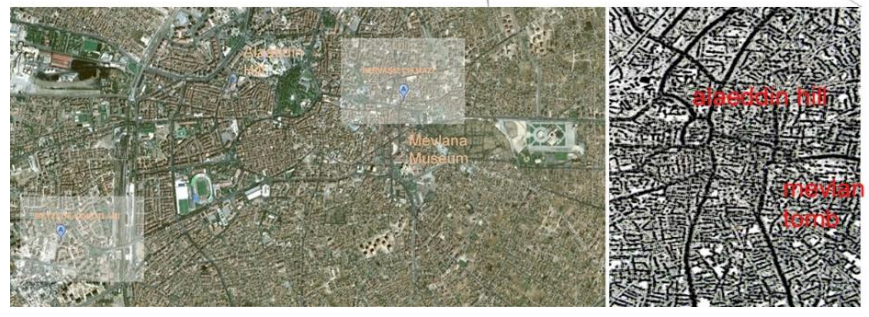

The Karatay district, a sub-center in the historical city texture close to the Mevlana Museum, contains many cul-de-sacs that still reflect a traditional Turkish urban life style (Figure 7).
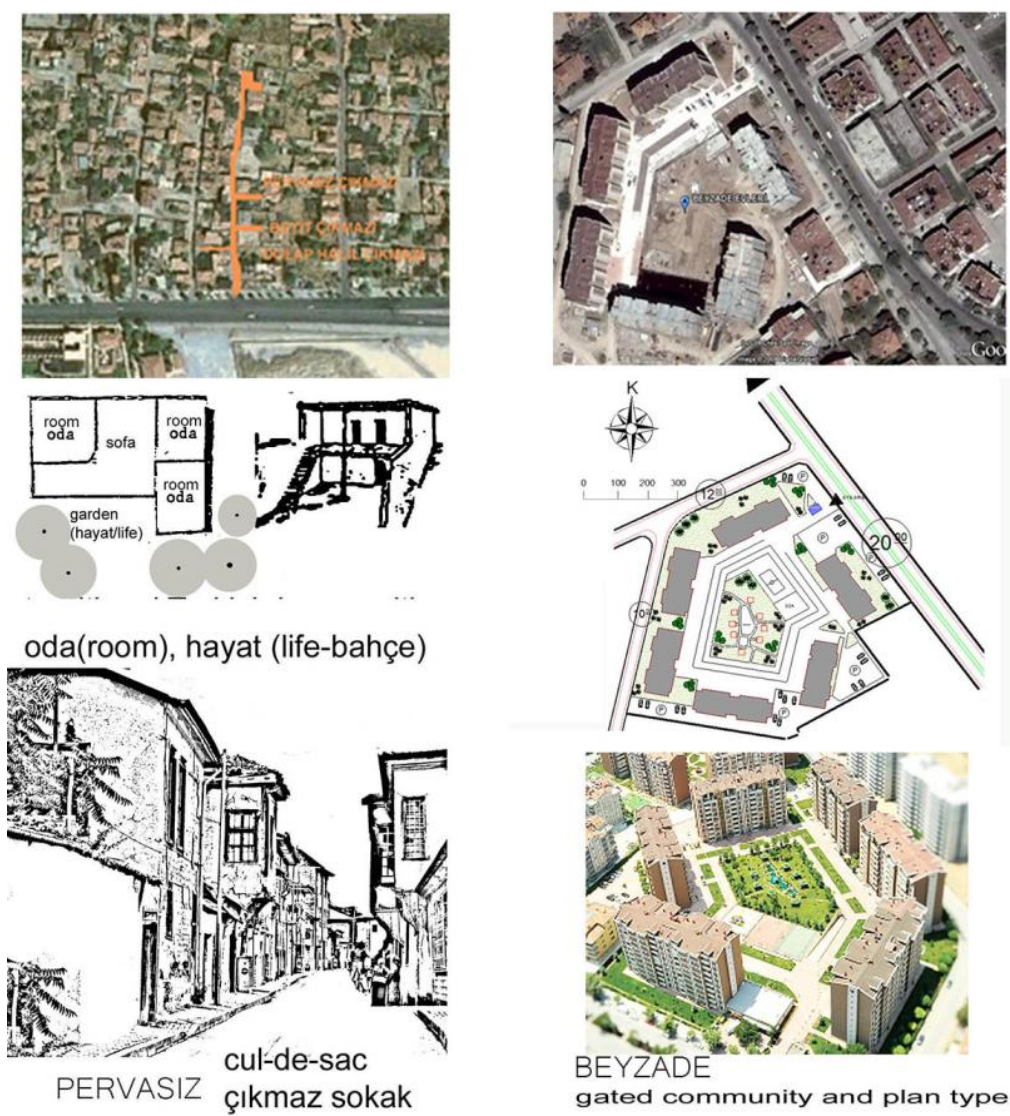

The Karatay district, located in the northeast part of Konya, includes the historical city center and where today not only the spatial properties of traditional Anatolian settlements but also the life style has been conserved. Within the scope of this study, the selected area has a number of cul-de-sacs that show the typical properties of a traditional Turkish city organization. In other words, these cul-de-sacs are socially and physically conserved and are similar to each other. The cul-de-sac selected as a case study, 
Pervasız Çlkmazl, is taken as a closed neighborhood. The other selected example of closed neighborhood is a gated community, the Beyzade Housing Complex, which is located in the Meram district, a sub-center in the southwest part of the city. They have been analyzed according to the topics of site planning, layout properties, resident properties and social infrastructure properties (Table 1).

Table 1: Analysis Statements of Gated Community in Konya-Site Planning and Layout Properties

\begin{tabular}{|c|c|c|c|c|c|}
\hline \multicolumn{6}{|c|}{$\begin{array}{l}\text { THE MACRO ANALYSIS OF GATED COMMUNITY - Site Planning and Layout } \\
\text { Properties }\end{array}$} \\
\hline $\begin{array}{l}\text { physical } \\
\text { location } \\
\text { and } \\
\text { relations } \\
\text { hip with } \\
\text { the } \\
\text { city } \\
\text { center }\end{array}$ & $\begin{array}{l}\text { Density of } \\
\text { Population(pe } \\
\text { rson) }\end{array}$ & $\begin{array}{l}\text { Total } \\
\text { Area } \\
\left(\mathrm{m}^{2}\right)\end{array}$ & $\begin{array}{l}\text { Total } \\
\text { Building } \\
\text { Area } \\
\left(\mathrm{m}^{2}\right)\end{array}$ & $\begin{array}{l}\text { Starting } \\
\text { and } \\
\text { finishing } \\
\text { dates }\end{array}$ & $\begin{array}{l}\text { Ownerships } \\
\text { (name of firm) }\end{array}$ \\
\hline $\begin{array}{l}\text { URBAN } \\
\text { CENTER } \\
\text { Meram } \\
\text { District } \\
\text { Havzan } \\
\text { Quarter }\end{array}$ & 1000 & $\begin{array}{l}136,729 \\
m^{2}\end{array}$ & $\begin{array}{l}97,631 \\
\mathrm{~m}^{2}\end{array}$ & $\begin{array}{l}\text { PHASE } \\
\text { 1: } 2004 \\
\text { April- } \\
\text { Decemb } \\
\text { er } \\
\text { PHASE } \\
\text { 2: } 2007 \\
\text { Decemb } \\
\text { er } \\
\text { Centrali } \\
\text { zed } \\
\text { purchas } \\
\text { e }\end{array}$ & $\begin{array}{l}\text { (Seha Yapı, } \\
\text { purchased from } \\
\text { the } \\
\text { Municipality of } \\
\text { Konya) } \\
\text { Seha Yapı }\end{array}$ \\
\hline \multicolumn{6}{|c|}{ THE MICRO ANALYSIS OF GATED COMMUNITIES - Residential Properties } \\
\hline \multicolumn{2}{|c|}{$\begin{array}{l}\text { Total Number } \\
\text { of Blocks }\end{array}$} & $\begin{array}{l}\text { Total } \\
\text { Number } \\
\text { of } \\
\text { Apartme } \\
\text { nts }\end{array}$ & $\begin{array}{l}\text { Number } \\
\text { of } \\
\text { Floors } \\
\text { (each } \\
\text { block) }\end{array}$ & $\begin{array}{l}\text { Number } \\
\text { of } \\
\text { rooms in } \\
\text { each } \\
\text { Apartme } \\
\text { nt }\end{array}$ & $\begin{array}{l}\text { Floor Area of } \\
\text { Apartments }\end{array}$ \\
\hline \multicolumn{2}{|l|}{12} & 216 & 8 & $\begin{array}{l}4+1 \\
\text { (The top } \\
\text { units are } \\
\text { duplex) }\end{array}$ & $185 \mathrm{~m}^{2}$ (net) \\
\hline \multicolumn{6}{|c|}{$\begin{array}{l}\text { THE MICRO ANALYSIS OF GATED } \\
\text { Properties }\end{array}$} \\
\hline $\begin{array}{l}\text { Total } \\
\text { green } \\
\text { area }\end{array}$ & $\begin{array}{l}\text { Indoor Sports } \\
\text { Field }\end{array}$ & $\begin{array}{l}\text { Pool } \\
\text { Area }\end{array}$ & $\begin{array}{l}\text { Childre } \\
\mathrm{n} \\
\text { Playgro } \\
\text { und } \\
\text { Area }\end{array}$ & $\begin{array}{l}\text { Shoppin } \\
\text { g Center, } \\
\text { Commer } \\
\text { cial } \\
\text { Units }\end{array}$ & $\begin{array}{l}\text { Entertainment } \\
\text { Hobby } \\
\text { Cafe- } \\
\text { Restaurant }\end{array}$ \\
\hline $\begin{array}{l}2220 \\
m^{2}\end{array}$ & $\begin{array}{l}\text { Fitness center } \\
360 \mathrm{~m}^{2}\end{array}$ & - & $50 \mathrm{~m}^{2}$ & $300 \mathrm{~m}^{2}$ & - \\
\hline
\end{tabular}

Alver (2010) has socially described the Beyzade Housing Complex by means of interviews made with 35 different residents. All the chosen interviewees were from different genders, ages, education levels and occupations. Each interview took between two to three hours in the home or office of the interviewee, in friendly and 
informal circumstances. Since The Beyzade Housing Complex is in the Meram District - an area of high income - it is neither too far from the city center, nor so close to the chaos of the city. The Beyzade Housing Complex was constructed for middle- and highincome economic levels. It consists of 216 residential units with open spaces, sports facilities, a meeting hall, commercial (shopping) units and a common area for social activities, all surrounded by walls with security for 24 hours a day and 7 days a week. It is not possible to claim that this chosen example presents the general properties of all gated communities in Konya. However, it is also a representative example.

Şerife Adacı (Figure 8a), an 82-year-old woman who lives on the Perfasiz Cul-de-Sac has stated: "We are a very large family and all relatives have been living in this cul-de-sac since 1940, although my grandsons and granddaughters have moved to Istanbul for their college education. I have never changed my house and my street. Sometimes my son complains about lack of comfort in the house because it is always cold in the winter. But he forgets that our neighbors are our relatives and we all eat together, and we financially support each other. I usually sit in front of my door, under that green tree, and greet my friends and relatives. In the street, I prepare food for the winter with my neighbor. My eldest son never ever moves to another house. I never let this. Being a large family and living together in this cul-de-sac is an honor to us."

Güllü Adacı (Figure 8b), a 30-year-old woman and daughter-inlaw of Şerife Adacı who also lives on the Perfasız Cul-de-Sac stated: "When I got married and joined this family, it was a bit difficult for me to adapt to life in this cul-de-sac. However, I eventually got used to it. I cleaned the street as if it were mine, because it is really mine. I am happy living here. At night the street becomes so dark, I wish that the municipality would bring some street lights to our cul-de-sac."

Children (Figure 8c) playing outside on Perfasız Cul-de-Sac stated: "We always play in the street and around it. We bike safely. We wish we had a football area. We have problems going to school because our school bus does not reach our house. On cold winter mornings, we have to walk far to reach a bus-stop." 

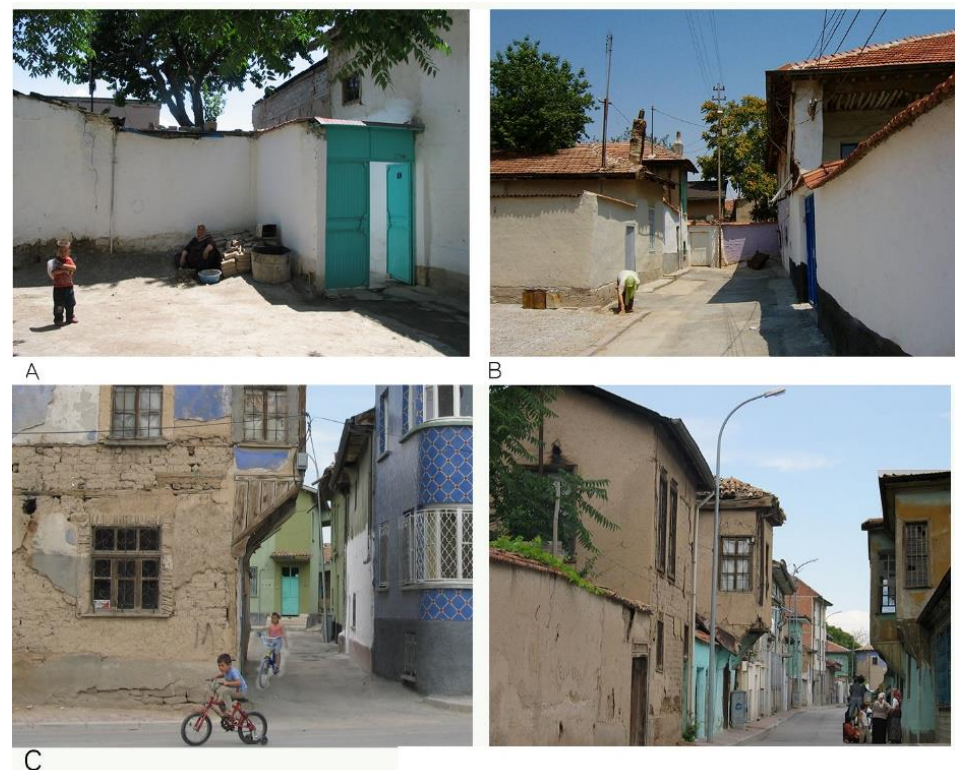

A young woman who did not want to mention her name and who lives on the Perfasız Cul-de-Sac (Figure 9), stated: "We are living in that old house and on the cul-de-sac as if we were in a village. In the city, people are always complaining about everything. But we are all right with our simple life. I love my neighbors. I myself feel safe in that street. No cars, no danger. We all know each other. We are even aware that you have come to take photos for a while. Maybe you do not meet all of us, but everyone in this street knows why you are here and that you are from a university, because we always share [all information]. It is very important for us to keep our neighbors from danger. We keep to each other and to this street. This street is my living room without a roof. While I chat and drink tea with the other women, my child is playing in the cul-de-sac."
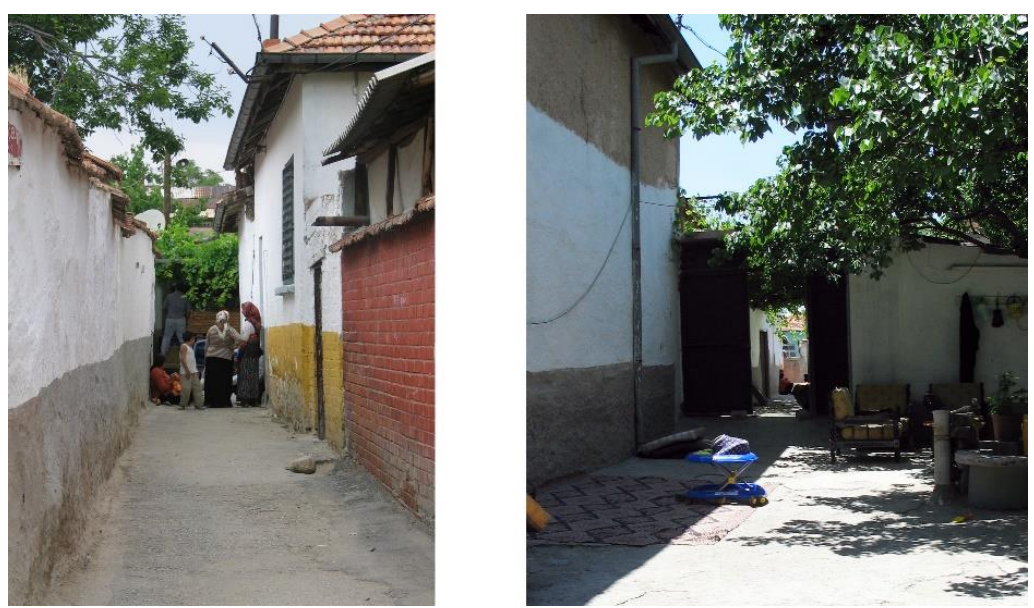

Ahmet Sayıcl, who lives in the Beyzade Housing Complex gated community (Figure 10.a), stated: "We are lucky because it is possible to directly access the main road. Our gate is secure and modern. I feel myself like I am a selected one. However, I miss my old neighborhood. In Beyzade, no one knows each other. We are all busy. [We have] no time to visit our neighbors. We only meet with
Figure 10: The Beyzade Housing Complex gate with security.

Figure 8.A: An old woman who is proud of her cul-de-sac and her big family. 8.B:People living on Perfasız Cul-de-Sac accept that the street is their territory and they clean it. 8.C:Children playing in the street and bicycling safely. 
each other at the official monthly community meeting to discuss problems of maintenance of the surroundings."

Children playing outside at the Beyzade Housing Complex gated community (Figure 10b) stated: "We have a playground area and a bicycle path. We have a security guard who protects us 24-7."

Figure 9. Residents chat, sit, and come together in the cul-de-sac.
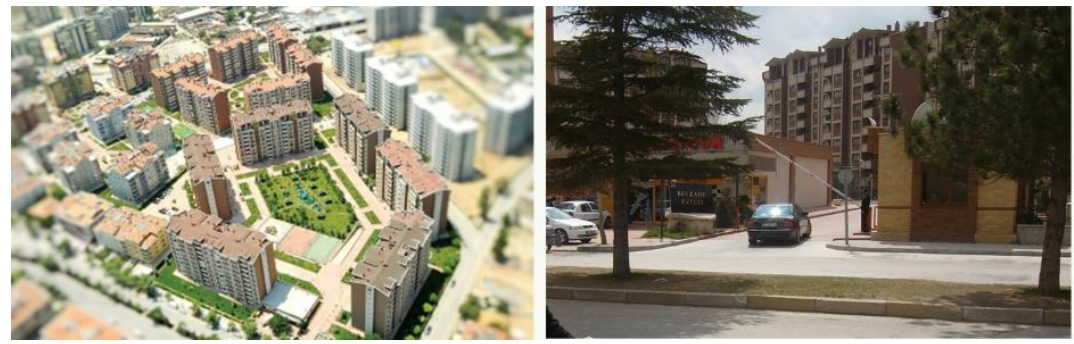

Table 2: Comparison between Pervasiz Cul-de-Sac and the Beyzade Housing Complex gated community.

\begin{tabular}{|c|c|c|}
\hline & $\begin{array}{l}\text { Pervasiz } \\
\text { CUL-DE-SAC }\end{array}$ & $\begin{array}{lcc}\text { Beyzade Housing } & \text { Complex } \\
\text { GATED COMMUNITY } & \\
\end{array}$ \\
\hline SECURITY & $\begin{array}{l}\text { In spite of not taking } \\
\text { special technical or } \\
\text { legal precautions for } \\
\text { urban crime or } \\
\text { vandalism, safety is } \\
\text { provided by means of } \\
\text { intimacy. To behave } \\
\text { and feel as an owner of } \\
\text { the cul-de-sac, being } \\
\text { well-known and being } \\
\text { appropriated provide a } \\
\text { special kind of security. } \\
\text { However, a special } \\
\text { security measure is } \\
\text { required, dwellers } \\
\text { stated that they felt } \\
\text { quite secure in } \\
\text { comparison with } \\
\text { another living space. }\end{array}$ & $\begin{array}{l}\text { There are high walls, an entrance } \\
\text { gate with barriers and security } \\
\text { guards. The housing estate } \\
\text { management stated that they will } \\
\text { set up CCTV cameras and an alarm } \\
\text { system. Security is provided with } \\
\text { a system based on technological } \\
\text { devices, gated barriers, walls, } \\
\text { fences, security guards and } \\
\text { identity control at the entrance } \\
\text { gate. }\end{array}$ \\
\hline $\begin{array}{l}\text { TRANSPORTATION } \\
\text { PROPERTIES }\end{array}$ & $\begin{array}{l}\text { Being a narrow street } \\
\text { makes motorized } \\
\text { vehicle transportation } \\
\text { impossible. }\end{array}$ & $\begin{array}{l}\text { It is possible to directly access the } \\
\text { housing complex from the main } \\
\text { road. The ground floor is arranged } \\
\text { as a car park. }\end{array}$ \\
\hline HOUSE PROPERTIES & $\begin{array}{l}\text { House units are not } \\
\text { sufficiently heated in } \\
\text { the winter. The use of } \\
\text { garden and street is of a } \\
\text { vital importance. } \\
\text { Gardens and streets } \\
\text { shared by the neighbors } \\
\text { are maintained and } \\
\text { cleaned. Night lighting } \\
\text { is not available. }\end{array}$ & $\begin{array}{l}\text { It has a modern structure material, } \\
\text { high specifications, heat, sound, } \\
\text { insulation, communication and } \\
\text { infrastructure as well as high } \\
\text { comfort conditions. }\end{array}$ \\
\hline HOUSE PREFERENCES & $\begin{array}{l}\text { Dwellers living on } \\
\text { Pervasiz Street made } \\
\text { their preferences under } \\
\text { the influence of } \\
\text { economical, social and } \\
\text { cultural inputs. } \\
\text { Relatives who know } \\
\text { each other and people } \\
\text { who are relatives } \\
\text { perceive that living } \\
\text { side-by-side is an } \\
\text { advantage in } \\
\text { overcoming economical }\end{array}$ & $\begin{array}{l}\text { Dwellers have preferred Beyzade } \\
\text { Housing Estate because they aim } \\
\text { to live under more secure and } \\
\text { comfortable conditions and form } \\
\text { the social and physical } \\
\text { environment with the people of } \\
\text { same social-economical level } \\
\text { similar to themselves. }\end{array}$ \\
\hline
\end{tabular}


Neighborhood from Cul-De-Sacto Gated Comunity in Turkish Urban Culture: The "Fina"

\begin{tabular}{|c|c|c|}
\hline & $\begin{array}{l}\text { and social difficulties } \\
\text { they encounter. }\end{array}$ & \\
\hline TECHNOLOGY & $\begin{array}{l}\text { Since there are no } \\
\text { infrastructure and bus } \\
\text { services, it is bereft of } \\
\text { technological facilities. }\end{array}$ & $\begin{array}{l}\text { Any basic requirement and } \\
\text { technology is used in a high ratio } \\
\text { and quality. }\end{array}$ \\
\hline COMMON USE & $\begin{array}{l}\text { Dead-end-streets are } \\
\text { spaces of greeting, } \\
\text { socializing, conversing, } \\
\text { and resting through } \\
\text { living together with } \\
\text { neighbors. Though } \\
\text { children have not been } \\
\text { organized, they create a } \\
\text { secure playground on } \\
\text { the street. }\end{array}$ & $\begin{array}{l}\text { Common spaces are utilized } \\
\text { independently of people and } \\
\text { groups with individual } \\
\text { inclinations. Living in the closed } \\
\text { housing estate has not affected the } \\
\text { neighborhood relations in a } \\
\text { negative or positive manner. } \\
\text { However, those who knew each } \\
\text { other before moving to the } \\
\text { housing estate use common areas } \\
\text { in social interaction. Common } \\
\text { areas such as playgrounds, } \\
\text { walking paths, bicycle paths, cafés, } \\
\text { and sports facilities are } \\
\text { comfortable. }\end{array}$ \\
\hline RULES & $\begin{array}{l}\text { Rules generated from } \\
\text { values based on } \\
\text { tradition, morals and } \\
\text { religion are established } \\
\text { by inclination of the } \\
\text { residents. }\end{array}$ & $\begin{array}{l}\text { Rules based on certified and } \\
\text { legitimate living and spatial } \\
\text { arrangements are established. }\end{array}$ \\
\hline $\begin{array}{l}\text { NEIGHBORHOOD } \\
\text { RELATIONS }\end{array}$ & $\begin{array}{l}\text { There are very close } \\
\text { and informal } \\
\text { neighborhood relations } \\
\text { based on sharing. Any } \\
\text { dweller of the street } \\
\text { knows each other and } \\
\text { has contact with each } \\
\text { other. } \\
\text { preparation of winter } \\
\text { foods is made through } \\
\text { helping each other and } \\
\text { gathering at the } \\
\text { doorways in the streets. } \\
\text { Women do not take part } \\
\text { in business life, they } \\
\text { gather on the dead-end- } \\
\text { street, clean, sweep the } \\
\text { fronts of their houses } \\
\text { and make tea-chat with } \\
\text { each other after their } \\
\text { husbands go to the } \\
\text { work. }\end{array}$ & $\begin{array}{l}\text { The neighborhood is a very formal } \\
\text { structure. Short visits are made } \\
\text { only. The number of people } \\
\text { known by each resident is } \\
\text { generally restricted to their } \\
\text { encounters in the elevators and } \\
\text { car park. All residents of the } \\
\text { housing estate only come together } \\
\text { in management meetings where } \\
\text { joint resolutions are adopted. } \\
\text { Acquaintance with } 1-2 \text { residents } \\
\text { having contact with other families } \\
\text { from the period before moving to } \\
\text { the housing estate. Residents are } \\
\text { not curious about who lives in the } \\
\text { buildings outside of the gated } \\
\text { community. }\end{array}$ \\
\hline $\begin{array}{l}\text { SOCIO-ECONOMIC } \\
\text { STATUS }\end{array}$ & $\begin{array}{l}\text { Low-income and high- } \\
\text { income families live } \\
\text { side-by-side on the } \\
\text { street. It has been } \\
\text { determined that } \\
\text { families living towards } \\
\text { the end of the cul-de-sac } \\
\text { are of higher economic } \\
\text { level. }\end{array}$ & $\begin{array}{l}\text { A homogeneous group with } \\
\text { middle- and high-income levels } \\
\text { living together. }\end{array}$ \\
\hline PRIVACY & $\begin{array}{l}\text { Women who } \\
\text { particularly spend their } \\
\text { life at home as a result } \\
\text { of loyalty to traditional } \\
\text { and religious roots have } \\
\text { weak relationships with } \\
\text { public. The end of the } \\
\text { cul-de-sac, which } \\
\text { changes from semi- } \\
\text { public to semi-private, } \\
\text { is used. }\end{array}$ & $\begin{array}{l}\text { Privacy has been identified with } \\
\text { sovereign boundaries without } \\
\text { holding to gender identity. }\end{array}$ \\
\hline $\begin{array}{ll}\text { FAMILY } & \text { AND } \\
\text { RELATIVE RELATIONS }\end{array}$ & $\begin{array}{l}\text { Street dwellers are } \\
\text { there for three } \\
\text { generations and any } \\
\text { one apart from two }\end{array}$ & $\begin{array}{l}\text { Families living in the housing } \\
\text { estate are nuclear families } \\
\text { composed of parents and children. } \\
\text { Single residents also live here. }\end{array}$ \\
\hline
\end{tabular}




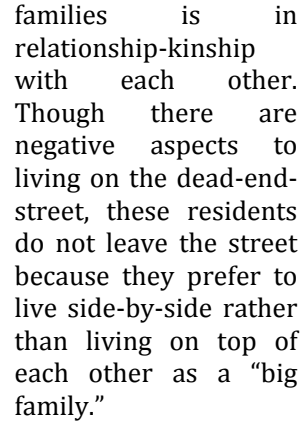

Table 2, below, has been prepared from observations and interviews with 15 residents of Perfasiz Cul-de-Sac and 25 residents of the Beyzade Housing Complex gated community.

\section{CONCLUSION}

Cul-de-sacs in the traditional Turkish city are not only a good example of social relations but also "Using Public Space as if it were Private/Semi-Private" process. In the traditional urban texture of Turkish cities, the cul-de-sac is a semi public street that is mainly a safe playing area as well as a semi-private social space for greeting, socializing, sitting and resting. The cul-de-sac may be defined as the sitting room of the neighborhood in traditional usage with four tall walls around it but without a ceiling. However, cul-de-sacs are viewed as a problem for circulation in modern cities, and they are not appreciated. Gated communities, which in this study are called a different kind of cul-de-sac, have started to become popular in modern Turkish cities. Both the culde-sac and the gated community have an entrance on only one side and are connected to another larger public street by that one entrance. Like cul-de-sacs, gated communities may also be labeled as "Using Public Space as if It Were Private/Semi-Private." On the other hand, gated communities are based on fear about a neighborhood and have been transferred from a foreign culture outside of Turkey.

The result expected from this study was not only to determine the similarities and differences pertaining to cul-de-sacs and gated communities but also to reveal the positive values generated or existing in these two living areas and provide feedback with the potential of reflecting each other. When describing the culture of cul-de-sacs and gated communities, we managed to understand their particular meaning of space. We learned, by studying cul-desacs, the ideas of neighborhood relationships, intimacy, and respect to nature and human being. The cul-de-sac addresses a range of inter-disciplinary issues such as crime, walkability, housing preferences, traffic behavior, traffic safety, cost, sustainability and social interaction. In the modern age and 
modern city, these same concepts - especially crime, housing preferences and social interaction - create gated communities that may be labeled as a different type of cul-de-sac. One of the significant problems of today's cities is the sharp-edged transition between private and public space. The cul-de-sac has offered an alternative solution to the sharp-edged transition problem, with particular buildings between public and private spaces which provide soft, gradual and hierarchic transition. On the other hand, a community gate which may be called a kind of cul-de-sac creates segregation not familiar to the neighborhood relationships of Turkish culture. How have human behaviors and perceptions of the neighborhood changed from traditional to modern, namely from cul-de-sac to gated community? Answering that question requires adoption of positive aspects of cul-de-sacs onto gated communities - or vice versa.

\section{REFERENCES}

Aktüre, S. (1978). 19. Yüzyıl Sonunda Anadolu Kenti Mekânsal Yapı Çözümlemesi (The Analysis of Structural Anatolian City Space in the last 19th Century, Middle East Technical University Press, Ankara.

Alver, K. (2010). Steril Hayatlar (Steril Lifes). İstanbul: Hece.

Abu-Lughod, J. (1987). "The İslamic City, Historic Myth, İslamic City: Historic Myth", İslamic Essence Contemporary Relevance, International Journal of Middle East Studies.12,30

Acar, E. (1975). Osmanlı Anadolu Kentinde Mülkiyet-Doku Illişkileri, (Basılmamış Yüksek Lisans Tezi), ODTÜ Mimarlık Fakültesi, Ankara.

Aru, K.A. (1998),Yıldız Sey (Ed.), Tarihten Günümüze Anadolu'da Konut ve Yerleşme (The Settlement and Resident in Anatolian Region From the History to Today), (p. 329-334), İstanbul: Tarih Vakfi.

Bala, A. H. (2003). Konut Alanlarında Kentsel Arayüzlerin Düzenlenmesine Yönelik Analitik Bir Çerçeve, Selçuk Üniversitesi Fen Bilimleri Enstitüsü, Doktora Tezi, Konya.

Bala, A. H., \& Nafa, H. (2008). "Le Cul-de-sac". On-site Review 19: Street, spring/summer 2008, Canada, 68-71.

Bala, A. H. Yoldaş, G.N, (2008). "Yarı /kamusal- yarı/ özel Bir Mekân; Çıkmaz Sokaklar" YAPI Mimarlık-Kültür-Sanat Dergisi sayı:322 Eylül Şubat 2008, sayfa 88-93, YEM yayınları, İstanbul

Bala, A..H., Çiftçi, C.., Meşhur, A.H.F. (2009). Reading Social (De/Re)- Constructions In Urban Neighborhoods: From Cul-De-Sacs To Gated Communities In Anatolian Cities,LIVENARCH IV International Congress (Re/De) 
Construction in Architecture, page 675-687, 9-11 July 2009, Trabzon- Turkey

Bala, A. H., (2010). The Privasition Of Public Space In Enclosed Neighbourhood Case; "Fina" To Gated Community, NHR 2010, WS NO: W02_Housing and Spatial Studies, 12th New Housing Researchers' Colloquium, 2-3 July, ITU, Faculty of Architecture, Taskisla, İstanbul-Turkey

Bala, A., H. (2012). "Çıkmaz Sokak"; Mahallenin Üstü Açık Oturma Odası", Güney Mimarlık, Sayı: 10, Aralık 2012, sayfa 27 33, Mimarlar Odası Adana Şubesi Yayını. 2007, sayfa 122125, Boyut yayınları, İstanbul.

Balamir, A. (1994). Kent Mekânları Sonatı (The Sonato Of Urban Spaces). In İ. Tekeli (Ed.), Kent Planlama, Politika, Sanat (s. 105-113). Ankara: Middle East Technical University.

Baykara, T. (1985). Konya In Seljuklu Periot. Ankara: Ministry of Culture and Tourism.

Berktay, A. (1996). Modernleşme Sürecinde Osmanlı Kentleri Editör:Raul Dumont ve Francois Georgeon Tarih Vakfı Yurt Yayınları, İstanbul.

Blakely, E. J, Snyder, M. G. (1997). Fortress America. Gated Communities in the United States. Washington DC and Cambridge: Brookings Institution and Lincoln Institute of Land Policy.

Borsdorf, A. (2002). Barrios cerrados en Santiago de Chile, Quito y Lima: tendencias de la segregacio'n socioespacialen capitales andinas. In. L. F. Cabrales Barajas (Ed.), Latinoame'Rica: Paı'Ses Abiertos, Ciudadescerradas (pp. 581-610). Mexico: Universidad de Guadalajara, UNESCO.

Calthorpe, P. (1994). The New American Metropolis: Ecology, Community \& American Dream, Princeton Press, New York.

Caldeira, T. P. (2000). City of Walls: Crime, Segregation and Citizenship in Sao Paulo. Berkeley: CA University of California.

Carvalho, M., Varkki George, R. \& Anthony, K. (1997). Residential satisfaction in Gate-guarded Neighborhoods in Brazil. Environment and Behavior, 29, 734-768.

Cozens, P., Hillier, D. (2008). The Shape of Things to Come: New Urbanism, the Grid and the Cul-De-Sac. International Planning Studies,13:1, 51-73.

Çelik, Z. (1996). 19.Yüzyılda Osmanlı Başkenti Değişen İstanbul Türk Tarih Vakfı Yurt Yayınları İstanbul.

Çevik, S., Özen, H. (1995). Özel Kamusal Mekan Olgusunun Geleneksel ve Günümüz Yaşama Çevrelerinde İrdelenmesi, Uluslar arası 7. Yapı ve Yaşam Fuarı Kongresi, Bursa 
Denel, S. (1982). Batılaşma Sürecinde İstanbul'da Tasarım ve Dış Mekanda Değişim ve Nedenleri (In The Period of Westernization Design and Changes in Istanbul and The Reasons of The Changes). Ankara: Middle East Technical University.

Duany, A., Plater-Zyberk E., Alminana R. (2003). The New Civic Art: Elements of Town Planning. New York: Rizzoli International Publications. ISBN 0-8478-2186-2

Duany, A., Plater-Zyberk, E. (1992). Towns \& Town-Making Principles, Harvard University Graduate School of Design, Cambridge.

Erdem, R., Özcan, K. (2004). XVI.Yüzyll Anadolu-Osmanlı Kentlerinde Çıkmaz Sokak Olgusunun Kökenleri Üzerine Bir Araştırma, Selçuk Üniversitesi BAP Proje No: 2000/049,s.8-21, Konya.

Fabiyi, 0. (2004). Gated Neighbourhoods and Privatisation of Urban Security in Ibadan Metropolis. No. 16 IFRA. Ibadan: Occasional.

Greenstein, R., Sabatini, F. \& Smolka (2000). Urban Spatial Segregation: Forces, Consequences, And Policy Responses. Land Lines, 12, 6. 66.

Grunebaum,G. (1961), Medieval Islam: A Study in Cultural Orientation. Second edition. Chicago, London: University of Chicago.

Gustave, G. (1946) The Structure of the Muslim Town, Islam, 19, 141-158.

Güner, D. (2010). İstanbul Kıyı Alanlarında Değişen Kamusallıklar http://www.archplus.net/index.php?s=Publikationen\&c $=237$

Hakim, B. (2007). Generative Processes for Revitalising Historic Towns or Heritage Districts Albuquerque. Urban Design International, 12, 87-99.

Hakim, B. (2010) The Islamic City and its Architecture: A Review Essay. Third World Planning Review, 12, 1, 75.

Hassan, R. (1972). Islamond Urbanization in the Medieval Middle East. Ekistis, No 195, 86

Hillier, B., Hanson, J. (1984). The Social Logic of Space. Cambridge: Cambridge University.

Kartz, P. (1994). The New Urbanism: Toward an Architecture of Community; Mc Graw-Hill, Inc. New York.

Keleș, R. (1999). Kent Bilim Terimleri Sözlüğü (The Terminology Dictionary of The City Science. Ankara: İmge.

Kubat, A., Asami, Y., Istek, İ. (2001). Characterization of Street Networks in Turkish-Islamic Urban Form. (Proceedings). 3rd International Space Syntax Symposium, Atlanta. 
Kubat A.S., Topçu M. (2009). Antakya ve Konya tarihi kent dokularının morfolojik açıdan karşılaştırılması. International Journal of Human Sciences, 6(2), 334-347.

Landman, K. (2002). Gated Communities in South Africa: Building Bridges or Barriers?.Paper presented at the International Conference on Private Urban Governance, Mainz, Germany, June 6 -9.

Landman, K. (2004). "Who owns the roads? Privatising Public space in South African cities through neighbourhood enclosures". Publications of CISR Building and Construction Technology South Africa.

Lapidus, I. M. (1967). Muslim Cities in The Later Middle Ages. Cambridge: Harvard University.

Low, S. M. (2000). The Edge and the Center: Gated Communities and the Discourse of Urban Fear. Issue American Anthropologist,103, 45-58. Retrieved March 18, 2001 from Wiley Online.

Marcuse, P. (2001). “Enclaves yes, ghettos, no: segregation and the state" Paper presented in the International Seminar on Segregation in the City Lincoln Institute of Land Policy, Cambridge, MA, 25-28 July.

Massey, D.,\& Denton, N. (1993). American Apartheid: Segregation and the Making of the Underclass. Cambridge: MA, Harvard University.

Mingione, E. (1996). Urban Poverty and the Underclass A Reader. Oxford: Blackwell.

Morris, A. (1979). History of Urban Form Before the Industrial Revolutions. London: George Godwin Limited.

Morrow-Jones, H., Irwin, E. \& Roe, B. (2004). Consumer preference for neotraditional neighbourhood characteristics, Housing Policy Debate, 15(1), pp. 171-202

Moughtin, C. (1992). Urban Design-Street and Square, Great Britain: Butterworth Architecture.

Mumford, L. (1989). The City In History. New York: Harvest Book.

Newman, O. (1972). Defensible Spaces, People \& Design in Violent City. London: Architectural.

Pinto, Rovira A. (2002). Los barrios cerrados de Santiago de Chile: en busca de la seguridad y la privacidadperdidas, in: L. F. Cabrales Barajas (Ed.), Latinoame'rica: países abiertos, ciudades cerradas (pp. 351-369). Guadalajara. Mexico: Universidad de Guadalajara, UNESCO.

Raymond, A. (1994). Islamic City, Arab City: Orientalist Myths and Recent Views, British Journal of Middle Eastern Studies, Vol. 21, No. 1, pp. 3-18

Raymond, A. (1995). Osmanlı Döneminde Arap Kentleri (The Arabic Cities In Ottoman Period), translated by Bektay A., Tarih Vakfı Yurt Press, İstanbul. 
Roitman, S. (2005). Who Segregates Whom? The Analysis of a Gated Community in Mendoza, Argentina. Housing Studies, Vol. 20, No. 2, 303-321.

Rykwert, J. (1982). Learning From The Street, The Necessity of Artifice, s 102-113 New York Arredamento Mimarlık, s 9798, 2006/12.

Sauvaget, J. (1946). Historiens arabes : pages choisies, traduites et présentées par J. Sauvaget, Paris, 1946, in-8º br., 192 pages. Réimpression 1988.

Saoud, R. (2002).Introduction of the Islamic City. Manchoester: FSTC Limited.

Southworth, M.,\& Ben-Joseph, E. (2004). Reconsidering the Culde-sac. Access, 24, 28-33.

Sözen, M.,\&Tanyeli, U. (1992). Sanat Terimleri Sözlüğü (Art Terminology Dictionary). İstanbul: Remzi.

Stewing, R. (1966). İstanbul'da Çıkmaz Sokaklar (The Cul-de-sac İn İstanbul). T. Yazman and Ş. Yazman (trans), İstanbul: Baha.

Svampa, M. (2001). Los que ganaron. La vida en los countries y barrios privados. Buenos Aires: Biblos

Topçu, M. (2013). Impact of Gated Housing Estates on Housing Values; Case of Konya, Turkey, Research Ppares of Wroclaw University of Economics, Economy and Space, ISSN 1899-3192, 155-166

Yerasimos, S. (1996). Modernleşme Sürecinde Osmanlı Kentleri, Paul Dumont and Francois Georgeon (Ed), Ali Berktay (Trans), İstanbul: Tarih Vakfı Yurt.

Webster, C.J. (2002). Gated Cities of Tomorrow. Town Planning Review, 72: 149-170.

Wilson-Doenges, G. (2000). An exploration of sense of community and fear of crime in gated communities, Environment and Behavior, 32, pp. 597-611.

Wilson, W. J. (1987). The Truly Disadvantaged; The Inner City, The Underclass and Public Policy. Chicago: The University.

\section{Resume}

Havva Alkan Bala received B.Arch. degree (1995) from Middle East Technical University. Her PhD. is about "An Analytical Frame towards the Arrangement of Urban Interfaces in Residential Areas" in Selçuk University Graduate School of Natural and Applied Sciences Department of Architecture, (1998-2003). She has been teaching since 1996 in different architectural schools at Selcuk University, Anadolu University, Kyrian American University, LUND University. She has published 36 article, 1 book and 4 section in books, 37 paper in the conferences about architectural and urban space and also cinema. She is currently a professor in the Department of Architecture The University of Konya Technical University. 